Copyright (C) 2015 by Academic Publishing House Researcher

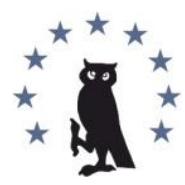

Published in the Russian Federation

European Researcher

Has been issued since 2010.

ISSN 2219-8229

E-ISSN 2224-0136

Vol. 90, Is. 1, pp. 4-16, 2015

DOI: $10.13187 /$ er.2015.90.4

www.erjournal.ru

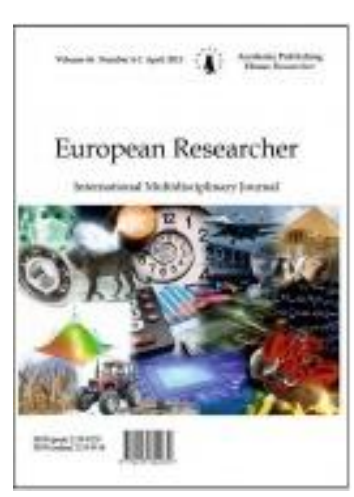

Historical sciences and archeology

Исторические науки и археология

UDC 908

\title{
The Soviet Society in Focus of a Regionalistika
}

\author{
${ }^{1}$ Irina V. Kornilova \\ ${ }^{2}$ Timur A. Magsumov
}

1-2 Naberezhnochelninsky Institute of socio-pedagogical technologies and resources, Russian Federation

423806, Republic of Tatarstan, Naberezhnye Chelny, Nizametdinov St., 28

PhD (History), Associate Professors

E-mail: ivkornilova@list.ru,nabonid1@yandex.ru

\section{Abstract}

The article presents the most significant intellectual achievements of the Russian historians in the field of historical study of local lore, regional and local history of the beginning of the XXI century in the conditions of radical transformations of the Russian historical science, its academic and high school structures, metropolitan and regional communities of the Russian scientists, their scientific communication connections and interactions with the western historiansregionalists are presented in article. There is $\mathrm{p}$ the attempt to consider the Soviet society through a prism of a combination and integration micro and macroapproaches in a locus of regional researches is made in this work. Methodological approaches of "modern local history" are considered in comparison with the developed local history practicians of an historiography. The authors comes to a conclusion about the beginning of the new period in the history of the local history movement connected with rehabilitation of traditional methods of an historiography, but on the new methodological basis with the purpose to save national historiographic traditions and to try to break the barriers existing in science.

Keywords: local history; historical study of local lore; history USSR; historiography; Soviet power and society.

\section{Введение}

В последнее двадцатилетие исследователи вовлечены в поле повышенного интереса общества и научных элит к феномену региона. Регионалистика стала претендовать на роль одной из цепей социогуманитарного знания. Некоторые историографы предрасположены связывать этот процесс с протекающим в российской истории методологическим поворотом в направлении микроисторического подхода и локальной истории. Подобные заявления в большей степени служат теоретическим обоснованием сложившейся практики работы 
провинциальных историков-профессионалов, нежели выявлением подлинных мотивов расширения фронта работ по местной истории. Представляется, что в первую очередь на это повлияли финансовые трудности постсоветского времени для занятия общероссийскими темами, открытие новых фондов в местных архивохранилищах и возможность изучения новых проблем.

К началу XXI века в отечественной исторической науке сложились отдельные направления, рассматриваемые как перспективные. Одним из них является «новая локальная история», которая нацелена на исследование с полидисциплинарных позиций локальных и региональных сообществ как субъектов исторического процесса в контекстуальном поле общероссийской истории. Этапы и особенности становления российской концепции локальной и региональной истории, равно и соответствующих ветвей историографии требуют специального изучения, поскольку это тесно связано с поисками новых способов познания сложных объектов и процессов, с конструированием междисциплинарных исследовательских моделей.

В изучении провинциальной истории историки-профессионалы столкнулись с любителями-краеведами, да и сам термин «локальная история» весьма близок краеведению. Для локального подхода свойственен ряд признаков, созвучных позициям краеведов: выявление частного, особенного, неповторимого, свойственного только для данной местности; территориальная ограниченность объекта изучения; интенсивное внимание к фактам и к источникам; комплексный подход к объекту изучения, целостность его изображения; включение объекта изучения в общий контекст региональной, отечественной и всемирной истории; эмоциональное, уважительное отношение к жившим в прошлом людям и описываемым событиям. Эти два направления, несмотря на разницу в целях и методологических подходах, должны идти рука об руку в решении задач изучения истории родного края.

Научный журнал «В мире научных открытий», обслуживающий профессиональные сообщества ученых, регулярно публикует на своих страницах статьи по истории российской провинции, что позволяет предпринять попытку реконструировать текущий историографический процесс.

\section{Материалы и методы}

В основе статьи лежит историографический обзор материалов по локальной истории, опубликованных на страницах журнала «В мире научных открытий». Работы анализируются нами исходя из многофакторного объяснения основных проблем советского общества, осмысленных в региональном ракурсе, с помощью общеисторических методов исследования и методов, используемых при изучении локальной истории.

\section{Обсуждение и результаты}

Исследованию событий Октября 1917 г. в рамках изучения региональной истории посвящена статья А.А. Черкасова [67], рассматривающая крестьянское движение на территории Черноморской губернии. Автор придерживается точки зрения, что в октябре 1917 г. был осуществлен переворот, приведший к власти большевиков. Интересны страницы, посвященные захвату большевиками власти вооруженным путем в Сочинском округе.

Тема советской власти и общества в условиях гражданской войны в региональном аспекте остается наименее изученной. Внимание исследователей привлекает история Чехословацкого корпуса, с выступлением которого долгое время связывали начало гражданской войны. Основой для публикации А.Н. Валиахметова [11] стали новые источники (более 30 дневников и воспоминаний) о вооруженной борьбе против чехословаков на территории Казанской губернии в 1918 г. Автор считает, что воспоминания участников боев дают возможность выявить уникальную информацию и стереотипные ситуации из истории Чехословацкого легиона. О.Г. Кирякова поднимает «чапаевскую тему» в истории гражданской войны в Поволжском крае [32]. В статье А.Н. Верижникова [12] выявлены причины, по которым в 1920 г. на территории Орловской губернии так и не смогли нормально функционировать созданные для подавления различных актов противодействия большевистскому режиму (кулацко-эссеровских восстаний, мятежей и др.) части особого назначения. А.А. Шувалов, анализируя архивные и мемуарные источники, 
предпринял попытку выяснить, почему офицерскому корпусу Вооруженных сил юга России и Российской армии Колчака не удалось решить проблему установления жесткой дисциплины [71]. В то же время Е.Ю. Бобкова показала динамику приращения исторических знаний по проблеме политического воспитания военнослужащих РККА в годы гражданской войны [10]. К.А. Зайцева и С.Н. Щерба подняли проблему судопроизводственной деятельности Тюменского Губернского Военно-революционного трибунала в 1918-1923 гг. [23]. Социально-трудовые отношения в России в период «военного коммунизма» рассмотрены в статье Б.Е. Рощина [53].

В центре внимания современных исследователей вновь очутилась, казалось бы, изученная в 1950-е гг. тема новой экономической политики, что обусловлено неоднозначностью подходов в поиске советским руководством экономической модели социализма. Сегодня акцент переместился на проблемы государственного регулирования сферы развития сельского хозяйства и товарно-денежных отношений. Причем в последние годы все большее внимание уделяется региональным аспектам проблемы. Так, Г.Р. Кельберер [31] размышляет о сельской кооперации 1920-х гг. в южных регионах Западной Сибири в ракурсе деятельности многопрофильного Ишимского Союза Сельскохозяйственных и Кредитных Кооперативов. Автор придерживается мнения, что кооперация в жизни сибирских крестьян являлась своеобразной формой удовлетворения своих экономических интересов, а кооперативные союзы сыграли большую роль в развитии российского кооперативного движения, особенно в Сибири, способствуя оптимизации сельскохозяйственного производства. Продолжая тему развития сельского хозяйства, В.Е. Иваненко и Н.В. Бахарева [27] на основе анализа животноводческой сферы сельского хозяйства в Зауралье обосновывают высокую эффективность развития отрасли исключительно мерами новой экономической политики. Хотя следует заметить, что авторы не учли тот факт, что высокие темпы роста во многом объяснялись «восстановительным эффектом». Среди факторов спада в развитии животноводства в 1921-1928 гг. авторы выделяют ценовую, налоговую и закупочную политику. Авторы продолжили тему развития зернового хозяйства Зауралья в 1914-1923 гг. [26], показав причины сельскохозяйственного кризиса в 1921-1922 гг., во время которого произошло резкое сокращение посевных площадей, валового сбора зерновых культур, появление новых культур, не свойственных данному региону, а также сокращение поголовья домашних животных, голод населения и его убыль.

Дискуссионной проблеме современной России - взаимоотношениям государства и частного капитала в торговле в период новой экономической политики - посвящена статья П.В. Юрлова [72]. На примере г. Красноярска Енисейской губернии автор рассматривает механизмы усиления и административного регулирования рынка (введение усиленного налогообложения, преимущественное кредитование государственной торговли, преимущества при перевозке товаров и др.). Интересен вывод автора о безотказности работы данной схемы вплоть до середины 1980-х гг. Причины кризиса политики советской власти в разрешении социальных проблем в уральских городах и деревнях в период новой экономической политики, таившей в себе широкие демократические начала, установлены в статье Н.P. Хамидуллина [65]. В рамках социальной политики советской власти конца 1920$\mathrm{x}$ - начала 1930-х гг. показаны особенности медицинского обслуживания населения города Вятки [54]. В контексте социальной политики в публикации И.С. Шиловой [70] на основе архивных материалов Пермского края представлен анализ репрессивной политики советской власти в отношении технической и педагогической интеллигенции в 1930-е гг. На основе данных переписей 1920-х гг. В.А. Журавлевой определена динамика численности социальной группы «служащих» в уральских городах [22]. Автор пришел к выводу, что в течение 1920-1926 гг. увеличившаяся численно социальная группа «служащие» занималась оказанием нематериальных услуг государству и отдельным гражданам. Более того, изменилось и распределение городских служащих по группам занятий: если в 1920-1923 гг. наиболее многочисленным был делопроизводственный и учетно-контрольный персонал, служащие по охране безопасности, то в 1926 г. - специалисты, занятые в производственнораспределительной сфере. Особенности взаимоотношений сельских тружеников и советской власти Северного Кавказа в конце 1920-1930-х гг., по мнению Т.Н. Кожемяко, варьировались от ее полного принятия и одобрения до полного отторжения [34]. 
Тема социального обеспечения нетрудоспособных граждан в инвалидных домах Сибири в 1920-1930-х гг. поднята в статье А.С. Ковалева [33]. Выводы автора о неравномерности распределения вещевого довольствия между разными категориями инвалидов обусловлены использованием классового принципа, порождающего дискриминацию в обеспечении лиц, не имевших трудового стажа. В статье Н.А. Личак [40] исследованы особенности и проблемы изъятия церковных ценностей в Ярославской губернии в 1922 г.

Внимание исследователей приковано к одному из трагических эпизодов российской истории - голоду 1933 г. Так, Н.Е. Каунова в своей работе [30] на основе анализа аграрной политики государства, дает оценку причин, динамики и демографических последствий голода в самом важном зерновом районе страны - Средне-Волжской деревне. В частности, автор считает, что 1932 г. стал завершающим в действии имеющих естественное происхождение факторов демографических процессов. После голода обозначилась тенденция неуклонного уменьшения жизненных сил деревни. Искажение исторических фактов голода 1932-1933 гг. представлено в статье Д.Ю. Касынцева [29].

И.А. Гридунова на материалах Алтая [17] выявляет формы взаимодействия прокуратуры и средств массовой информации в период новой экономической политики, когда происходил процесс формирования основ советской прокуратуры, просуществовавшей в течение долгого времени. Следует заметить, что В.В. Фролов [64] продолжает исследование деятельности региональных прокуратур на материалах Псковской области в трудный период первого послевоенного десятилетия. В статье А.А. Иванова и Т.А. Приваловой исследованы проблемы становления и развития уголовно-исполнительной системы Байкальского региона - Республики Бурятия и Иркутской области [28]. В.Ж. Дорохов в своей работе [20], сравнивая качества милиционера времен СССР и периода демократической России, пришел к выводу, что советский милиционер был в более выгодном свете.

Анализ роли театра в повседневной жизни городского населения Западной Сибири в 1920-1930-е гг. дан в публикации Е.С. Пономаревой [50]. Автор утверждает, что массы городских людей требовалось приучить к городскому образу жизни, в том числе и к способам проведения досуга. В данном случае на театр возлагалась функция привнесения культурности в широкие городские слои населения, оформляя и нормализуя, согласно образцам культурности, их обыденную жизнь. Феномен территориальности искусства Дальнего Востока в контексте межкультурного взаимодействия рассмотрен в статье В.А. Королевой [36]. Автор выявила аспекты социальной мотивации формирования векторов концертной практики местных музыкантов и гастролеров, особенности тематики и содержания концертного репертуара и в целом вопросы развития и трансформации региональной музыкальной культуры на Дальнем Востоке в 1920-1930-е гг. В статье О.В. Тузовой рассмотрена музыкально-культурная система в 1939-1945 гг. на материалах Поволжья - Куйбышевской, Казанской, Пензенской, Ульяновской и Саратовской областей [6o].

Пространственно-территориальная мобилизационная политика Советского государства в предвоенное десятилетие рассмотрена О.Ю. Репуховой [52] на основе анализа условий и динамики формирования системы приграничных полос в Карелии. Основные этапы развития и становления «Осовиахим» Иркутской области, созданного в январе 1927 г. и его деятельности, в том числе в учреждениях и учебных заведениях, посвящена статья B.В. Теплухина [59].

К сожалению, менее вдумчиво авторы журнала относятся к исследованию региональных аспектов военного времени (1941-1945 гг.). Лишь П.С. Попов, М.Н. Волошина, А.М. Украинцев, В.В.Федотова, Т.Ю. Хаустова, Г.В. Алжейкина, Т.Г. Новоселова и предприняли попытки изучения этого сложного периода. В публикациях данных авторов рассмотрены вопросы социально-культурного пребывания в Иркутской области депортированных литовских граждан, обвиненных в пособничестве немцам [51]; проверочно-фильтрационных лагерей, где содержались побывавшие в плену бойцы Красной Армии, а также лица призывного возраста, оказавшиеся на оккупированной территории [14]; процессы эвакуации и реэвакуации населения в Мордовии в 1941-1948 гг. [62]; вклад военнопленных и интернированных в реконструкцию индустрии Южного Урала во время и после Второй мировой войны [61]; структура санитарной службы 45 авиационной дивизии 
дальнего действия базировавшейся на аэродроме Московской области в 1942-1945 гг. [66] В работе Г.В. Алжейкиной поднята проблема деятельности в годы Великой Отечественной войны профессиональных коллективов на примере фронтовой бригады, состоящей из артистов Чувашского государственного ансамбля песни и пляски [3]. Объектом исследования Т.Г. Новоселовой стала «Книга памяти» г. Новокузнецка, содержащая сведения о кузбассцах, погибших в годы Великой Отечественной войны [48].

Послевоенная фаза истории советской коммунистической цивилизации представлена в журнале публикациями, отражающими проблемы социально-экономического и культурного развития страны в соответствии с правлением советских вождей.

Вопросы взаимоотношений местных органов власти и провинциальной интеллигенции в послевоенный период (1946-1953 гг.) рассмотрены на примере Горьковской области И.В.Филипчуком [63]. Проблема адаптации к мирной жизни городского населения Краснодарского края в послевоенный период исследована М.С. Дмитриевской [19]. Автор показала специфику повседневной жизни населения края, взаимодействие его с властью и обществом.

Тема реорганизации советской системы управления экономикой хрущевского периода в региональном аспекте рассмотрена в серии статей П.Е. Соборнова [55-57], объектом исследования которого является один из крупнейших регионов страны - Горьковский экономический административный район. Автор, исследуя процесс формирования Горьковского совнархоза и реформы партийных органов, приходит к неутешительному выводу о провале реформ на региональном уровне. Острые противоречия внутри органов власти стали, по мнению автора, основными причинами нарастания негативных тенденций в развитии советской экономической модели. В статье И.А. Мороз [44] поднята не только проблема повышения качества товаров в советской торговой системе 1950-1960-х гг. на основании архивных источников и материалов периодической печати, но и дан анализ путей решения этой проблемы.

Проблемы молодежного движения в отечественной историографии стали предметом изучения С.В. Гусевой [18]. Автор акцентирует внимание на работах, освещающих трудности, недостатки и проблемы в жизни советской молодежи, работающей на ударных стройках Южного Урала в 1956-1965 гг. И.Ф. Айсин рассматривает вопросы подготовки сельскохозяйственных кадров в системе профессионально-технического образования Оренбургской области [2].

Продолжает исследование социально-экономических проблем брежневского периода на материалах Поволжских областей А.В. Захаров, Среднего Зауралья - О.В. Афонасьева [6]. В частности, А.В.Захаровым рассмотрена система бытового обслуживания сельского населения [25], а также формирование собственной структуры подготовки кадров мелиораторов в Саратовской области в целях обеспечения сельского хозяйства квалифицированными специалистами [24]. Достижения и проблемы политики обеспечения сельского хозяйства механизаторскими кадрами и закрепления профессиональных кадров на селе Среднего Зауралья проанализированы в источниковедческой работе О.В. Афонасьевой и О.П. Еланцевой [7]. Продолжая исследование темы культурнообразовательной инфраструктуры села Среднего Зауралья в 1965-1985 гг., О.В. Афонасьева представила анализ изменений в культурной и образовательной сферах, произошедших в сельской местности в ходе политики реформирования сельского хозяйства [5]. Особенности государственной политики в сфере культуры Красноярского края исследованы Е.И. Лобыневой [41]. Кадровая политика в ракурсе привлечения молодежи к управлению государством, пополнения рядов компартии и создания надежного молодого резерва в Свердловской области в 1980-х гг. стала объектом изучения в статье Н.А. Тарасовой [58]; патриотического воспитания молодежи средствами массовой информации на примере Республики Адыгея - в статье М.А. Ешева [21]. Исторический опыт интеграции высшего образования и производства в 1970-е гг. на примере отдельно взятого региона исследован А.А. Арслановой [4]. Особенности подготовки кадров квалифицированных учителей для средних общеобразовательных и профессиональных учебных заведений Дагестана в 19701980-е гг. отражены в публикации Х.С. Муцалханова и Н.Ш. Мугутдиновой [47], Н.Ф. Мусаевой и С.Г. Хиясовой [45]; в Кемеровской области в 1930-1985 гг. - в работе И.В. Шаляпиной [69]. Вопросы политического воспитания личного состава Советской армии 
послевоенного периода подняты в статье Е.Ю. Бобковой [9].

Интересны работы, рассматривающие на фоне эпохи аналитические биографии видных деятелей советской эпохи - Ф.Х. Мустафиной, министра образования Башкирии [46], Г.Я. Сокольникова, народного комиссара финансов РСФСР и СССР [16].

Ряд статей журнала обращены к различным темам социокультурной жизни советского общества: повседневной культуре народов Среднего Поволжья [39], Сибири [8, 37, 38]; феномену стиляг как альтернативной молодежной советской субкультуре [15]; кампании против популярной музыки, начатой постановлением ЦК КПСС [68]; женскому вопросу в советском обществе [1]; вопросам развития краеведения [13, 35, 42, 43, 49].

В целом, материалы журнала «В мире научных открытий» не дают исчерпывающей информации по многим актуальным вопросам советского времени, однако они важны в плане изучения регионального ракурса советского общества.

\section{Выводы}

Региональная история является существенной и неотъемлемой частью исторических изысканий, как за рубежом, так и в России. Она прошла продолжительный период становления и развития, постоянно соотносясь с общим историографическим процессом. Развитие науки делает окончательно очевидным тот факт, что подлинно поднять постижение местной истории до уровня ключевого, равноправного исторического жанра возможно не только накоплением работ, исполненных в традиционной манере изложения материала, но и посредством значительного обновления инструментария исследователей, овладением современными междисциплинарными социогуманитарными методиками и подходами. Отличную возможность предоставляет нам в этом случае изучение истории повседневности, культурно-антропологических аспектов жизнедеятельности местного социума. Все это даст возможность избежать периферийности в научной деятельности и позволит историкам, занимающихся региональной историей, опираясь на опыт прошлого, используя местный материал, внести свой вклад в становление новых направлений, развивающихся в исторической дисциплине в целом.

\section{Примечания:}

1. Агеева В.В. От Александры Коллонтай до «Pussy riot»: женщины, гендер и власть советской и постсоветской России сквозь призму англо-американской историографии // В мире научных открытий. 2014. № 11.8 (59). С. 2888-2901.

2. Айсин И.Ф. Решение кадрового вопроса в период освоения целинных земель в Оренбургской области // В мире научных открытий. 2010. № 4-3. С. 36-38.

3. Алжейкина Г.В. Чувашский государственный ансамбль песни и пляски на фронтах Великой Отечественной войны // В мире научных открытий. 2014. № 7 (55). С. 160182.

4. Арсланова А.А. Сотрудничество высшей школы и базовых предприятий региона при подготовке специалистов без отрыва от производства: опыт 70-ых годов // В мире научных открытий. 2014. № 1.1 (49). С. 465-480.

5. Афонасьева О.В. Культурно-образовательная структура села Среднего Зауралья (1965-1985 гг.) // В мире научных открытий. 2014. № 11.8 (59). С. 3256-3264.

6. Афонасьева О.В. Сельскохозяйственное производство Среднего Зауралья 19651985: годы «застоя» или «стабильного развития»?// В мире научных открытий. 2013. № 11.3 (47). C. 26-32.

7. Афонасьева О.В., Еланцева О.П. Государственная политика в области обеспечения села механизаторскими кадрами 1965-1985 гг. в оценке исторических источников (на материалах Среднего Зауралья)// В мире научных открытий. 2014. № 11.8 (59). С. $3205-3215$.

8. Бакулина Т.И., Кучева А.В. Облик послевоенного провинциального города (Тюмень второй половины 40-х - первой половины 50-х гг. XX века) // В мире научных открытий. 2013. № 11.3 (47). С. 33-38.

9. Бобкова Е.Ю. Генезис отечественной историографии политического воспитания личного состава Советской армии послевоенного периода (1945-1991 г.) на современном этапе развития исторической науки // В мире научных открытий. 2014. № 9.3 (57). С. 1093- 
1105.

10. Бобкова Е.Ю. Политическое воспитание военнослужащих РККА в годы российской гражданской войны: обзор истории изучения проблемы (вторая половина 80-х гг. XX века - до настоящего времени) // В мире научных открытий. 2014. № 1.1 (49). C. $693-711$.

11. Валиахметов А.Н. Чехословацкий легион в Казанской губернии в 1918 году. Воспоминания // В мире научных открытий. 2012. № 7.1. С. 141-159.

12. Верижников А.Н. Отряды особого назначения на территории Орловской губернии в 1920 г.: организация и формирование // В мире научных открытий. 2012. № 7.1. C. 109-123.

13. Волкова А., Зудина Т., Каленкова О.С. История села Большие Ключищи // В мире научных открытий. 2010. № 6-2. С. 328-332.

14. Волошина М.Н. Проверочно-фильтрационные лагеря в системе политических репрессий (1941-1946 гг.) // В мире научных открытий. 2010. № 4-12. С. 87-89.

15. Габур В.С. Влияние моды на культурное сознание: феномен стиляг в СССР // В мире научных открытий. 2012. № 11. С. 270-281.

16. Гребнев А.Г. Г.Я. Сокольников - народный комиссар финансов РСФСР и СССР (ноябрь 1922 - январь 1926 г.) // В мире научных открытий. 2010. № 5-1. С. 132-135.

17. Гридунова И.А. Формы взаимодействия прокуратуры и прессы в 1920-е гг. (на материалах Алтая) // В мире научных открытий. 2010. № 4-12. С. 103-105.

18. Гусева С.В. Историография социализации молодежи ударных комсомольских строек Южного Урала (1956-1965 гг.) // В мире научных открытий. 2012. № 11. С. 229-241.

19. Дмитриевская М.С. Проблема адаптации к мирной жизни населения городов Краснодарского края в 1945-1959 гг. // В мире научных открытий. 2010. № 4-12. С. 89-91.

20. Дорохов В.Ж. Нарушения дисциплины и законности в советской милиции 19531968 гг. // В мире научных открытий. 2013. № 11.3 (47). С. 81-91.

21. Ешев М.А. Роль СМИ в процессе патриотического воспитания молодежи в Республики Адыгея // В мире научных открытий. 2010. № 4-12. С. 7-8.

22. Журавлева В.А. Социальная группа «служащие» среди горожан Урала (по материалам переписей 1920-х гг.) // В мире научных открытий. 2014. № 1.1 (49). С. 712-722.

23. Зайцева К.А., Щерба С.Н. Документирование судопроизводственной деятельности Тюменского Губернского Военно-Революционного трибунала (19181923 гг.) // В мире научных открытий. 2010. № 3-1. С. 110-114.

24. Захаров А.В. Подготовка кадров мелиораторов в Саратовской области в 1960-х начале 1970-х гг. // В мире научных открытий. 2011. Т. 16. № 4. С. 35-41.

25. Захаров А.В. Служба быта в социальной структуре сельских районов в 19651985 гг. на материалах областей Поволжья // В мире научных открытий. 2012. № 4.2. C. 46-62.

26. Иваненко В.Е., Бахарева Н.В. Зерновое хозяйство Тюменской (Тобольской) губернии в 1914-1923 гг. и кризис 1921-1922 гг.// В мире научных открытий. 2014. № 11.3 (59). C. 1150-1165.

27. Иваненко В.Е., Бахарева Н.В. Новая экономическая политика и ее влияние на развитие животноводства в Зауралье (1921-1928 гг.) // В мире научных открытий. 2012. № 11.2. C. 11-29.

28. Иванов А.А., Привалова Т.А. Из истории уголовно-исполнительной системы Байкальского региона // В мире научных открытий. 2010. № 5-1. С. 126-129.

29. Касынцев Д.Ю. Проблемы искажения исторических фактов голода в СССР 19321933 годов // В мире научных открытий. 2010. № 4-12. С. 43-44.

30. Каунова Н.Е. Демографические последствия голода в начале 1930-х гг. в СреднеВолжской деревне // В мире научных открытий. 2010. № 6.2. С. 333-336.

31. Кельберер Г.Р. Деятельность Ишимского Союза сельскохозяйственных и кредитных кооперативов 20-х годов XX века как пример оптимизации сельского хозяйства на юге Западной Сибири // В мире научных открытий. 2010. № 4-12. С. 91-93.

32. Кирякова О.Г. Гражданскя война в Поволжье // В мире научных открытий. 2010. № 4-8. С. 124-126.

33. Ковалев А.С. Материально-бытовая обеспеченность нетрудоспособного населения 
в инвалидных домах Сибири в 20-30-х гг. XX в.// В мире научных открытий. 2013. № 9.1 (45). С. $77-97$.

34. Кожемяко Т.Н. Советская власть и крестьянство Северного Кавказа в конце 19201930-е гг.: особенности взаимоотношений // В мире научных открытий. 2013. № 11.3 (47). C. $102-106$.

35. Корнилова И.В. Ренессанс елабужского краеведения // В мире научных открытий. 2011. Т. 16. № 4. С. 120-124.

36. Королева В.А. Музыкальная концертная деятельность на Дальнем Востоке России 1920-1930-х гг.: векторы демократизации и межкультурного взаимодействия // В мире научных открытий. 2014. № 11.8 (59). С. 3095-3110.

37. Кучева А.В. Основные черты городской среды Тюмени в послевоенный период (1945-1953 гг.) // В мире научных открытий. 2013. № 11.3 (47). С. 102-106.

38. Кучева А.В. Человек в провинциальном городе: повседневная жизнь в послевоенные годы (1945-1953) // В мире научных открытий. 2014. № 11.8 (59). С. 3130-3145.

39. Лепешкина Л.Ю. Похоронно-поминальный обряд как механизм сохранения традиций в культуре народов Среднего Поволжья (XIX в.) // В мире научных открытий. 2012. № 7.1. С. 160-187.

40. Личак Н.А. К вопросу об изъятии церковных ценностей в Ярославской губернии в 1922 г. // В мире научных открытий. 2010. № 2-1. С. 74-76.

41. Любынева Е.И. Государственная политика в сфере культуры в Красноярском крае в 1960-1980-е гг. // В мире научных открытий. 2013. № 5.3 (41). С. 53-64.

42. Магсумов Т.А. Учащаяся молодежь в общественной жизни Казани начала XX века // В мире научных открытий. 2011. Т. 16. № 4. С. 50-58.

43. Магсумов Т.А., Корнилова И.В. Сочинские страницы современной советологии // В мире научных открытий. 2014. № 1 (49). С. 16-22.

44. Мороз И.А. Некоторые проблемы качества товаров и пути их решения в советской торговле 50-60-х годов XX века // В мире научных открытий. 2014. № 11.8 (59). C. 3165-3179.

45. Мусаева Н.Ф., Хиясова С.Г. Становление художественно-педагогического образования в Дагестане 1970-1990-е годы // В мире научных открытий. 2014. № 11.8 (59). C. $3180-3193$.

46. Мустафина Ф.З., Магсумов Т.А., Корнилова И.В. Женское лицо российского образования: Ф.Х. Мустафина // В мире научных открытий. 2014. № 5 (53). С. 18-25.

47. Муцалханов Х.С., Мугутдинова Н.Ш. Подготовка учителей трудового обучения в средних специальных и высших учебных заведениях Дагестана в начале 70-х - середине 80-х годов XX века // В мире научных открытий. 2011. Т. 16. № 4. С. 64-70.

48. Новоселова Т.Г. «Всекузбасская книга памяти» как источник по изучению истории Великой Отечественной войны (по материалам «Книги Памяти» г. Новокузнецка) // В мире научных открытий. 2010. № 6-2. С. 396-398.

49. Оюн А.М. Становление и развитие детской музыкальной школы в Тувинской автономной области в 1947-1960 годы // В мире научных открытий. 2013. № 11.3 (47). C. 126-131.

50. Пономарева Е.С. Театр и повседневность в 1920-30-е годы // В мире научных открытий. 2010. № 4-12. С. 55-56.

51. Попов П.С. К вопросу о литовских спецпоселенцах в Аларском районе Иркутской области // В мире научных открытий. 2010. № 6-2. С. 356-359.

52. Репухова О.Ю. Система пограничных полос в Карелии в 1930-х годах // В мире научных открытий. 2014. № 11.8 (59). С. 3216-3227.

53. Рощин Б.Е. Принудительный труд в России в период «военного коммунизма»: историко-правовой аспект // В мире научных открытий. 2010. № 2-1. С. 77-81.

54. Семенова А.Ю. Особенности медицинского обслуживания населения г. Вятки в конце 20-30-х гг. XX века // В мире научных открытий. 2010. № 3-3. С. 107-108.

55. Соборнов П.Е. Протоколы заседаний парткома Горьковского (Волго-Вятского) совнархоза 1957-1966 годов как исторический источник // В мире научных открытий. 2012. № 11.2. C. 93-105.

56. Соборнов П.Е. Совнархоз Горьковского экономического административного 
района в общественном сознании современников // В мире научных открытий. 2012. № 4.2. C. 188-201.

57. Соборнов П.Е. Управленческая модернизация в СССР 1957-1962 годов в области промышленности строительства и партии (по материалам Горьковской области) // В мире научных открытий. 2012. № 11.2. С. 30-46.

58. Тарасова Н.А. Молодежь как резерв пополнения управленческих кадров в регионе в 1980 гг. (на материалах Свердловской области) // В мире научных открытий. 2010. № 1-1. C. 111-116.

59. Теплухин В.В. История оборонных организаций Иркутской области // В мире научных открытий. 2010. № 6-2. С. 417-420.

6о. Тузова О.В. Материальные ресурсы региональной музыкальной культуры в 19391945 гг.: проблема размещения (на примере Поволжья) // В мире научных открытий. 2013. № 11.3 (47). C. 155-169.

61. Украинцев А.М. Трудоиспользование военнопленных и интернированных в Челябинской области во время и после второй мировой войны // В мире научных открытий. 2012. № 4.2. С. 239-250.

62. Федотов В.В. Эвакуационные процессы в Мордовской АССР в 1941-1948 гг. // В мире научных открытий. 2013. № 11.3 (47). С. 177-182.

63. Филипчук И.В. Взаимоотношения местных органов власти и провинциальной интеллигенции в 1946-1953 гг. (на примере Горьковской области) // В мире научных открытий. 2013. № 11.3 (47). С. 183-188.

64. Фролов В.В. Основные направления деятельности региональных прокуратур РСФСР в первое послевоенное десятилетие (по материалам прокуратуры Псковской области) // В мире научных открытий. 2012. № 4. С. 77-85.

65. Хамидуллин Н.Р. Кризис социальной политики в первые годы советской власти на Урале: причины и пути решения // В мире научных открытий. 2010. № 3-2. С. 129-132.

66. Хаустова Т.Ю. Особенности организации санитарной службы 45 авиационной дивизии дальнего действия в период ее дислокации в поселке Стаханово (городе Жуковский) Московской области в 1942-1945 гг. // В мире научных открытий. 2013. № 1. C. $13-25$.

67. Черкасов А.А. Октябрь 1917 г. и его роль в формировании крестьянского движения на Черноморье // В мире научных открытий. 2010. № 2-1. С. 94-98.

68. Шадрин В.О. КПСС против популярной музыки в 1984 году // В мире научных открытий. 2013. № 11.3 (47). С. 200-204.

69. Шаляпина И.В. Становление и развитие системы педагогических училищ в Кемеровской области (1930-1985 гг.) // В мире научных открытий. 2010. № 4-12. С. 112-114.

70. Шилова И.С. К вопросу о фальсификации дел в отношении интеллигенции в 1930-е гг. (по материалам Пермского архива новейшей истории) // В мире научных открытий. 2011. Т. 16. № 4. С. 145-153.

71. Шувалов А.А. Боеспособность вооруженных сил внутренней контрреволюции на юге и востоке России в период гражданской войны // В мире научных открытий. 2014. № 7 (55). С. $70-90$.

72. Юрлов П.В. Политика государства по отношению к частному капиталу в торговле в период НЭПа (на примере Енисейской губернии) // В мире научных открытий. 2010. № 412. C. $95-97$.

\section{References}

1. Ageeva V.V. Ot Aleksandry Kollontay do «Pussy riot»: zhenshchiny, gender i vlast' sovetskoy i postsovetskoy Rossii skvoz' prizmu anglo-amerikanskoy istoriografii // V mire nauchnykh otkrytiy. 2014. № 11.8 (59). S. 2888-2901.

2. Aysin I.F. Reshenie kadrovogo voprosa $\mathrm{v}$ period osvoeniya tselinnykh zemel' $\mathrm{v}$ Orenburgskoy oblasti // V mire nauchnykh otkrytiy. 2010. № 4-3. S. 36-38.

3. Alzheykina G.V. Chuvashskiy gosudarstvennyy ansambl' pesni i plyaski na frontakh Velikoy Otechestvennoy voyny // V mire nauchnykh otkrytiy. 2014. № 7 (55). S. 160-182.

4. Arslanova A.A. Sotrudnichestvo vysshey shkoly i bazovykh predpriyatiy regiona pri podgotovke spetsialistov bez otryva ot proizvodstva: opyt 70-ykh godov // V mire nauchnykh 
otkrytiy. 2014. № 1.1 (49). S. 465-480.

5. Afonas'eva O.V. Kul'turno-obrazovatel'naya struktura sela Srednego Zaural'ya (19651985 gg.) // V mire nauchnykh otkrytiy. 2014. № 11.8 (59). S. 3256-3264.

6. Afonas'eva O.V. Sel'skokhozyaystvennoe proizvodstvo Srednego Zaural'ya 1965-1985: gody «zastoya» ili «stabil'nogo razvitiya»? // V mire nauchnykh otkrytiy. 2013. № 11.3 (47). S. 26-32.

7. Afonas'eva O.V., Elantseva O.P. Gosudarstvennaya politika v oblasti obespecheniya sela mekhanizatorskimi kadrami 1965-1985 gg. v otsenke istoricheskikh istochnikov (na materialakh Srednego Zaural'ya) // V mire nauchnykh otkrytiy. 2014. № 11.8 (59). S. 3205-3215.

8. Bakulina T.I., Kucheva A.V. Oblik poslevoennogo provintsial'nogo goroda (Tyumen' vtoroy poloviny 40-kh - pervoy poloviny 50-kh gg. XX veka) // V mire nauchnykh otkrytiy. 2013. № 11.3 (47). S. 33-38.

9. Bobkova E.Yu. Politicheskoe vospitanie voennosluzhashchikh RKKA v gody rossiyskoy grazhdanskoy voyny: obzor istorii izucheniya problemy (vtoraya polovina $80-\mathrm{kh}$ gg. KhKh veka do nastoyashchego vremeni) // V mire nauchnykh otkrytiy. 2014. № 1.1 (49). S. 693-711.

10. Bobkova E.Yu. Genezis otechestvennoy istoriografii politicheskogo vospitaniya lichnogo sostava Sovetskoy armii poslevoennogo perioda (1945-1991 g.) na sovremennom etape razvitiya istoricheskoy nauki // V mire nauchnykh otkrytiy. 2014. № 9.3 (57). S. 1093-1105.

11. Valiakhmetov A.N. Chekhoslovatskiy legion v Kazanskoy gubernii v 1918 godu. Vospominaniya // V mire nauchnykh otkrytiy. 2012. № 7.1. S. 141-159.

12. Verizhnikov A.N. Otryady osobogo naznacheniya na territorii Orlovskoy gubernii v 1920 g.: organizatsiya i formirovanie // V mire nauchnykh otkrytiy. 2012. № 7.1. S. 109-123.

13. Volkova A., Zudina T., Kalenkova O.S. Istoriya sela Bol'shie Klyuchishchi // V mire nauchnykh otkrytiy. 2010. № 6-2. S. 328-332.

14. Voloshina M.N. Proverochno-fil'tratsionnye lagerya v sisteme politicheskikh repressiy (1941-1946 gg.) // V mire nauchnykh otkrytiy. 2010. № 4-12. S. 87-89.

15. Gabur V.S. Vliyanie mody na kul'turnoe soznanie: fenomen stilyag v SSSR // V mire nauchnykh otkrytiy. 2012. № 11. S. 270-281.

16. Grebnev A.G. G.Ya. Sokol'nikov - narodnyy komissar finansov RSFSR i SSSR (noyabr' 1922 - yanvar' 1926 g.) // V mire nauchnykh otkrytiy. 2010. № 5-1. S. 132-135.

17. Gridunova I.A. Formy vzaimodeystviya prokuratury i pressy v 1920-e gg. (na materialakh Altaya) // V mire nauchnykh otkrytiy. 2010. № 4-12. S. 103-105.

18. Guseva S.V. Istoriografiya sotsializatsii molodezhi udarnykh komsomol'skikh stroek Yuzhnogo Urala (1956-1965 gg.) // V mire nauchnykh otkrytiy. 2012. № 11. S. 229-241.

19. Dmitrievskaya M.S. Problema adaptatsii $\mathrm{k}$ mirnoy zhizni naseleniya gorodov Krasnodarskogo kraya v 1945-1959 gg. // V mire nauchnykh otkrytiy. 2010. № 4-12. S. 89-91.

20. Dorokhov V.Zh. Narusheniya distsipliny i zakonnosti v sovetskoy militsii 19531968 gg. // V mire nauchnykh otkrytiy. 2013. № 11.3 (47). S. 81-91.

21. Eshev M.A. Rol' SMI v protsesse patrioticheskogo vospitaniya molodezhi v Respubliki Adygeya // V mire nauchnykh otkrytiy. 2010. № 4-12. S. 7-8.

22. Zhuravleva V.A. Sotsial'naya gruppa «sluzhashchie» sredi gorozhan Urala (po materialam perepisey 1920-kh gg.) // V mire nauchnykh otkrytiy. 2014. № 1.1 (49). S. 712-722.

23. Zaytseva K.A., Shcherba S.N. Dokumentirovanie sudoproizvodstvennoy deyatel'nosti Tyumenskogo Gubernskogo Voenno-Revolyutsionnogo tribunala (1918-1923 gg.)// V mire nauchnykh otkrytiy. 2010. № 3-1. S. 110-114.

24. Zakharov A.V. Podgotovka kadrov melioratorov v Saratovskoy oblasti v 1960-kh nachale 1970-kh gg. // V mire nauchnykh otkrytiy. 2011. T. 16. № 4. S. 35-41.

25. Zakharov A.V. Sluzhba byta v sotsial'noy strukture sel'skikh rayonov v 1965-1985 gg. na materialakh oblastey Povolzh'ya // V mire nauchnykh otkrytiy. 2012. № 4.2. S. 46-62.

26. Ivanenko V.E., Bakhareva N.V. Zernovoe khozyaystvo Tyumenskoy (Tobol'skoy) gubernii v 1914-1923 gg. i krizis 1921-1922 gg. // V mire nauchnykh otkrytiy. 2014. № 11.3 (59). S. 1150-1165.

27. Ivanenko V.E., Bakhareva N.V. Novaya ekonomicheskaya politika i ee vliyanie na razvitie zhivotnovodstva v Zaural'e (1921-1928 gg.) // V mire nauchnykh otkrytiy. 2012. № 11.2. S. 11-29.

28. Ivanov A.A., Privalova T.A. Iz istorii ugolovno-ispolnitel'noy sistemy Baykal'skogo 
regiona // V mire nauchnykh otkrytiy. 2010. № 5-1. S. 126-129.

29. Kasyntsev D.Yu. Problemy iskazheniya istoricheskikh faktov goloda v SSSR 19321933 godov // V mire nauchnykh otkrytiy. 2010. № 4-12. S. 43-44.

30. Kaunova N.E. Demograficheskie posledstviya goloda v nachale 1930-kh gg. v SredneVolzhskoy derevne // V mire nauchnykh otkrytiy. 2010. № 6.2. S. 333-336.

31. Kel'berer G.R. Deyatel'nost' Ishimskogo Soyuza sel'skokhozyaystvennykh i kreditnykh kooperativov 20-kh godov XX veka kak primer optimizatsii sel'skogo khozyaystva na yuge Zapadnoy Sibiri // V mire nauchnykh otkrytiy. 2010. № 4-12. S. 91-93.

32. Kiryakova O.G. Grazhdanskya voyna v Povolzh'e // V mire nauchnykh otkrytiy. 2010. № 4-8. S. 124-126.

33. Kovalev A.S. Material'no-bytovaya obespechennost' netrudosposobnogo naseleniya $\mathrm{v}$ invalidnykh domakh Sibiri v 20-30-kh gg. XX v. // V mire nauchnykh otkrytiy. 2013. № 9.1 (45). S. 77-97.

34. Kozhemyako T.N. Sovetskaya vlast' i krest'yanstvo Severnogo Kavkaza v kontse 19201930-e gg.: osobennosti vzaimootnosheniy // V mire nauchnykh otkrytiy. 2013. № 11.3 (47). S. $102-106$.

35. Kornilova I.V. Renessans elabuzhskogo kraevedeniya // V mire nauchnykh otkrytiy. 2011. T. 16. № 4. S. 120-124.

36. Koroleva V.A. Muzykal'naya kontsertnaya deyatel'nost' na Dal'nem Vostoke Rossii 1920-1930-kh gg.: vektory demokratizatsii i mezhkul'turnogo vzaimodeystviya// V mire nauchnykh otkrytiy. 2014. № 11.8 (59). S. 3095-3110.

37. Kucheva A.V. Osnovnye cherty gorodskoy sredy Tyumeni v poslevoennyy period (19451953 gg.) // V mire nauchnykh otkrytiy. 2013. № 11.3 (47). S. 102-106.

38. Kucheva A.V. Chelovek v provintsial'nom gorode: povsednevnaya zhizn' v poslevoennye gody (1945-1953) // V mire nauchnykh otkrytiy. 2014. № 11.8 (59). S. 3130-3145.

39. Lepeshkina L.Yu. Pokhoronno-pominal'nyy obryad kak mekhanizm sokhraneniya traditsiy v kul'ture narodov Srednego Povolzh'ya (XIX v.) // V mire nauchnykh otkrytiy. 2012. № 7.1. S. 160-187.

40. Lichak N.A. K voprosu ob iz"yatii tserkovnykh tsennostey v Yaroslavskoy gubernii v 1922 g. // V mire nauchnykh otkrytiy. 2010. № 2-1. S. 74-76.

41. Lyubyneva E.I. Gosudarstvennaya politika v sfere kul'tury v Krasnoyarskom krae v 1960-1980-e gg. // V mire nauchnykh otkrytiy. 2013. № 5•3 (41). S. 53-64.

42. Magsumov T.A. Uchashchayasya molodezh' v obshchestvennoy zhizni Kazani nachala KhKh veka // V mire nauchnykh otkrytiy. 2011. T. 16. № 4. S. 50-58.

43. Magsumov T.A., Kornilova I.V. Sochinskie stranitsy sovremennoy sovetologii // V mire nauchnykh otkrytiy. 2014. № 1 (49). S. 16-22.

44. Moroz I.A. Nekotorye problemy kachestva tovarov i puti ikh resheniya $\mathrm{v}$ sovetskoy torgovle 50-6o-kh godov XX veka // V mire nauchnykh otkrytiy. 2014. № 11.8 (59). S. 3165-3179.

45. Musaeva N.F., Khiyasova S.G. Stanovlenie khudozhestvenno-pedagogicheskogo obrazovaniya v Dagestane 1970-1990-e gody // V mire nauchnykh otkrytiy. 2014. № 11.8 (59). S. 3180-3193.

46. Mustafina F.Z., Magsumov T.A., Kornilova I.V. Zhenskoe litso rossiyskogo obrazovaniya: F.Kh. Mustafina // V mire nauchnykh otkrytiy. 2014. № 5 (53). S. 18-25.

47. Mutsalkhanov Kh.S., Mugutdinova N.Sh. Podgotovka uchiteley trudovogo obucheniya v srednikh spetsial'nykh i vysshikh uchebnykh zavedeniyakh Dagestana v nachale $70-\mathrm{kh}$ - seredine 80-kh godov XX veka // V mire nauchnykh otkrytiy. 2011. T. 16. № 4. S. 64-70.

48. Novoselova T.G. «Vsekuzbasskaya kniga pamyati» kak istochnik po izucheniyu istorii Velikoy Otechestvennoy voyny (po materialam «Knigi Pamyati» g. Novokuznetska) // V mire nauchnykh otkrytiy. 2010. № 6-2. S. 396-398.

49. Oyun A.M. Stanovlenie i razvitie detskoy muzykal'noy shkoly v Tuvinskoy avtonomnoy oblasti v 1947-1960 gody // V mire nauchnykh otkrytiy. 2013. № 11.3 (47). S. 126-131.

50. Ponomareva E.S. Teatr i povsednevnost' v 1920-30-e gody // V mire nauchnykh otkrytiy. 2010. № 4-12. S. 55-56.

51. Popov P.S. K voprosu o litovskikh spetsposelentsakh $\mathrm{v}$ Alarskom rayone Irkutskoy oblasti // V mire nauchnykh otkrytiy. 2010. № 6-2. S. 356-359.

52. Repukhova O.Yu. Sistema pogranichnykh polos v Karelii v 1930-kh godakh // V mire 
nauchnykh otkrytiy. 2014. № 11.8 (59). S. 3216-3227.

53. Roshchin B.E. Prinuditel'nyy trud v Rossii v period «voennogo kommunizma»: istoriko-pravovoy aspect // V mire nauchnykh otkrytiy. 2010. № 2-1. S. 77-81.

54. Semenova A.Yu. Osobennosti meditsinskogo obsluzhivaniya naseleniya g. Vyatki v kontse 20-30-kh gg. XX veka // V mire nauchnykh otkrytiy. 2010. № 3-3. S. 107-108.

55. Sobornov P.E. Protokoly zasedaniy partkoma Gor'kovskogo (Volgo-Vyatskogo) sovnarkhoza 1957-1966 godov kak istoricheskiy istochnik // V mire nauchnykh otkrytiy. 2012. № 11.2. S. 93-105.

56. Sobornov P.E. Sovnarkhoz Gor'kovskogo ekonomicheskogo administrativnogo rayona v obshchestvennom soznanii sovremennikov // V mire nauchnykh otkrytiy. 2012. № 4.2. S. 188-201.

57. Sobornov P.E. Upravlencheskaya modernizatsiya v SSSR 1957-1962 godov v oblasti promyshlennosti stroitel'stva i partii (po materialam Gor'kovskoy oblasti) // V mire nauchnykh otkrytiy. 2012. № 11.2. S. 30-46.

58. Tarasova N.A. Molodezh' kak rezerv popolneniya upravlencheskikh kadrov v regione $\mathrm{v}$ 1980 gg. (na materialakh Sverdlovskoy oblasti) // V mire nauchnykh otkrytiy. 2010. № 1-1. S. 111-116.

59. Teplukhin V.V. Istoriya oboronnykh organizatsiy Irkutskoy oblasti // V mire nauchnykh otkrytiy. 2010. № 6-2. S. 417-420.

6o. Tuzova O.V. Material'nye resursy regional'noy muzykal'noy kul'tury v 1939-1945 gg.: problema razmeshcheniya (na primere Povolzh'ya) // V mire nauchnykh otkrytiy. 2013. № 11.3 (47). S. 155-169.

61. Ukraintsev A.M. Trudoispol'zovanie voennoplennykh i internirovannykh v Chelyabinskoy oblasti vo vremya i posle vtoroy mirovoy voyny // V mire nauchnykh otkrytiy. 2012. № 4.2. S. 239-250.

62. Fedotov V.V. Evakuatsionnye protsessy v Mordovskoy ASSR v 1941-1948 gg. // V mire nauchnykh otkrytiy. 2013. № 11.3 (47). S. 177-182.

63. Filipchuk I.V. Vzaimootnosheniya mestnykh organov vlasti i provintsial'noy intelligentsii v 1946-1953 gg. (na primere Gor'kovskoy oblasti) // V mire nauchnykh otkrytiy. 2013. № 11.3 (47). S. 183-188.

64. Frolov V.V. Osnovnye napravleniya deyatel'nosti regional'nykh prokuratur RSFSR v pervoe poslevoennoe desyatiletie (po materialam prokuratury Pskovskoy oblasti) // V mire nauchnykh otkrytiy. 2012. № 4. S. 77-85.

65. Khamidullin N.R. Krizis sotsial'noy politiki v pervye gody sovetskoy vlasti na Urale: prichiny i puti resheniya // V mire nauchnykh otkrytiy. 2010. № 3-2. S. 129-132.

66. Khaustova T.Yu. Osobennosti organizatsii sanitarnoy sluzhby 45 aviatsionnoy divizii dal'nego deystviya v period ee dislokatsii v poselke Stakhanovo (gorode Zhukovskiy) Moskovskoy oblasti v 1942-1945 gg. // V mire nauchnykh otkrytiy. 2013. № 1. S. 13-25.

67. Cherkasov A.A. Oktyabr' $1917 \mathrm{~g}$. i ego rol' v formirovanii krest'yanskogo dvizheniya na Chernomor'e // V mire nauchnykh otkrytiy. 2010. № 2-1. S. 94-98.

68. Shadrin V.O. KPSS protiv populyarnoy muzyki v 1984 godu // V mire nauchnykh otkrytiy. 2013. № 11.3 (47). S. 200-204.

69. Shalyapina I.V. Stanovlenie i razvitie sistemy pedagogicheskikh uchilishch v Kemerovskoy oblasti (1930-1985 gg.) // V mire nauchnykh otkrytiy. 2010. № 4-12. S. 112-114.

70. Shilova I.S. K voprosu o fal'sifikatsii del v otnoshenii intelligentsii v 1930-e gg. (po materialam Permskogo arkhiva noveyshey istorii) // V mire nauchnykh otkrytiy. 2011. T. 16. № 4. S. $145-153$.

71. Shuvalov A.A. Boesposobnost' vooruzhennykh sil vnutrenney kontrrevolyutsii na yuge i vostoke Rossii v period grazhdanskoy voyny // V mire nauchnykh otkrytiy. 2014. № 7 (55). S. 70-90.

72. Yurlov P.V. Politika gosudarstva po otnosheniyu $\mathrm{k}$ chastnomu kapitalu $\mathrm{v}$ torgovle $\mathrm{v}$ period NEPa (na primere Eniseyskoy gubernii) // V mire nauchnykh otkrytiy. 2010. № 4-12. S. 95-97. 
УДК 908

\section{Советское общество в фокусе регионалистики}

${ }^{1}$ Ирина Валерьевна Корнилова

${ }^{2}$ Тимур Альбертович Магсумов

1-2 Набережночелнинский институт социально-педагогических технологий и ресурсов, Российская Федерация

423806, Республика Татарстан, г. Набережные Челны, ул. Низаметдинова, 28

Кандидаты исторических наук, доценты

E-mail: ivkornilova@list.ru, nabonid1@yandex.ru

Аннотация. В статье представлены наиболее значимые интеллектуальные достижения российских историков в области исторического краеведения, региональной и локальной истории начала XXI столетия в условиях коренных преобразований российской исторической науки, ее академических и вузовских структур, столичных и региональных сообществ российских ученых, их научно-коммуникативных связей и взаимодействий с западными историками-регионалистами. В работе делается попытка рассмотреть советское общество сквозь призму комбинации и интеграции микро и макроподходов в локусе региональных исследований. Методологические подходы «новой локальной истории» рассматриваются в сравнении со сложившимися краеведческими практиками историописания. Авторы приходят к выводу о начале нового периода в истории краеведческого движения, связанного с реабилитацией традиционных методов историописания, но на новом методологическом основании с целью уберечь национальные историографические традиции и попытаться преодолеть существующие в науке барьеры.

Ключевые слова: локальная история; историческое краеведение; история СССР; историография; советская власть и общество. 